\title{
Healthcare Deconcentration Program in the Karo District of Sumatra Utara Province
}

\author{
Februati Trimurni $^{1}$, Erika Revida ${ }^{2}$, Dayana $^{3}$ \\ \{februati@usu.ac.id ${ }^{1}$ \} \\ Universitas Sumatera Utara, Indonesia ${ }^{1,2,3}$
}

\begin{abstract}
This article aims to discuss the roles and urgency of the deconcentrated healthcare program at the district level. In order to discuss those issues, the decentralization perspective of Smith [1] is applied as the main theory. This study analyzes three themes, which are (1) how self-reliant is the region in healthcare sector financing, (2) responses of local governments regarding the role of the deconcentration programs, and (3) how is the contribution of the program to regional healthcare services. This research is a qualitative study using secondary data and in-depth interviews as the main data sources. The data analysis is conducted qualitatively by applying the triangulation method of data sources and applying data validation through credibility and conformity standards. This study finds that regional independence in healthcare sector financing is still low, the role of the program is still crucial for the region as well as the contribution of the programs can fill the gap of the local efforts on human resource development for medical and non-medical personnel. This study further recommends the need for the central government to plan and coordinate deconcentration programs with the regions so that future programs can better accommodate regional needs.
\end{abstract}

Keywords: Regional Autonomy, Deconcentration, Local Government, Regional Finance, Healthcare Sector

\section{Introduction}

The deconcentration program in the government administration system is not obviously a new phenomenon or one that is born since the 1998 political reforms. The concept of deconcentration in fact existed during the New Order era, namely through the regulation of Law No. 5/1974. Even though the national government at that time is managed centrally, this doesn't mean that it would eliminate the form of administrative decentralization. This reality supports the thesis stating that basically there is no system of government that is truly centralist or a government that is totally centralized. The difference in categorization between the centralized state and the decentralized management lies only in the direction in which the domination of government administration is emphasized.

Decentralization as the antithesis of centralization has various patterns and forms. Smith divides it into only two forms, namely political decentralization or commonly known as devolution, and administrative decentralization or deconcentration [1]. Bardhan in his study complements Smith's form of decentralization in the context of fiscal decentralization [2]. Other scientists such as Cheema and Rondinelli make a more complete categorization, namely deconcentration, delegation, devolution, and privatization [3]. The various choices for this form of decentralization in fact confuse the public, including government administrators at the 
national and regional levels, namely those who think that devolution is the only form of decentralization known in Indonesia. Meanwhile, various programs of delegation and deconcentration are not considered part of decentralization.

Apart from limiting the scope of deconcentration, it's intended to accelerate the realization of community welfare through improved services, empowerment, and community participation, as well as increasing regional competitiveness by taking into account the principles of democracy, equity, and justice [4]. It is in line with the goal of deconcentration as intended by Smith [1].

Healthcare sector services as objects in this study is a basic service that cannot be postponed. Because of the urgency and sacredness of this service, the global community made this sector a global priority as sparked in the Millennium Development Goals (MDGs) program. Indonesia as a country that is included in the global convention is no less serious with its initiatives to realize the agreement notably by regulating Law No 36/2009 concerning healthcare. This regulation has the original intend particularly to the national development and to increase the degree of public health as an investment for national development.

In the context of Indonesian decentralization, the deconcentration program will incrementally remove or transfer in accordance with the authority of the autonomous regions as mandated in Law No. 32/2004. To maximize health sector services in conditions of the low regional revenue, the majority of regions that have not fulfilled their obligations in budget allocation fully expect local non-revenue funds to provide health sector services. These funds are obviously sourced from higher levels of government which are provincial and national funds such as the general allocation fund (DAU), Special Allocation Fund (DAK), the Assistance Task Fund (DTP), and the Deconcentration Fund.

To completely eliminate deconcentration programs and funding, especially for the national healthcare sector, it seems that it still takes a long time and process. This is related to the regional financial capacity which is completely uneven from one region to another, the sustainability of previously implemented programs, or the readiness of the apparatus and human resources in autonomous regions to carry out similar programs. Before the deconcentration program has not been transferred to DAU or DAK or is in the current transition process, the program must be maintained at least to help autonomous regions to implement public healthcare services or add certain programs to the health sector which are considered to have gone unnoticed.

Looking at the various facts and phenomena arising from the deconcentration program and funding for the health service sector, this study will further discuss 3 (three) main themes. Firstly, how is the regional independence, in this case Karo District, related to the financing of public services in the health sector. Secondly, how the local government responds to the role and urgency of funding the health sector deconcentration. Thirdly, how the contribution of health sector deconcentration funding to health service programs in the regions.

\section{Method}

This study is conducted in Karo District, Sumatera Utara Province in 2020. It is a qualitative descriptive study relying on the availability of secondary data and in-depth interviews as the main data sources. Secondary data in this study are generally official local government documents directly obtained at the research location. In-depth interviews are generally conducted with local government officials, namely informants who occupy positions at echelon II, echelon III, and echelon IV levels in local government organizational units. Data 
validation with credibility and confirmation standards is carried out in this study [5]. Data analysis is carried out by adopting Creswel's data analysis cycle consisting of organizing data, reading and making memos, describing, classifying and interpreting, presenting, and visualizing data [6].

\section{Theoretical Review}

The study on deconcentration cannot be separated from the discussion related to decentralization in general. In the government administration system, there are two general methods which are centralization and decentralization. Centralization is defined as "to concentrate by placing power and authority in a center", while decentralization is interpreted as "to disperse or distribute power from the center" [7]. However, both centralized and decentralized administration systems are not two dichotomous concepts in reality but move along a continuum [8][9].

Decentralization itself is theoretically difficult to define because many perspectives and disciplines pay attention to this concept [10]. Cheema and Rondinelli define decentralization as the delegation of authority by the central government to local governments, central government units in the regions, local government implementing units, semi-government organizations, or non-governmental organizations [3]. Cheema and Rondinelli, furthermore, distinguishes decentralization into four forms: deconcentration, delegation, devolution, and privatization [3]. From the various forms of decentralization, devolution is a context that is commonly known and interpreted by the public. In Indonesia, in particular, the public only interprets decentralization as devolution. This is inseparable from the historical fact that devolution is the original form of decentralization and has become "the most common understanding of genuine decentralization" [11].

Deconcentration is generally interpreted as "the transfer of a number of administrative powers and responsibilities to lower levels of government that are still within the scope of the central government organization" [12]. The keyword for handing over of authority, in this case, is administrative authority, not authority that is political in nature as in the context of devolution. As such, the design and decision-making powers distributed by the central government to these various institutions are limited to administrative areas and of course not included in the political sphere.

\section{Results and Discussion}

\subsection{Regional Independence: High Dependence on the Central Budget}

The Regional Revenue and Expenditure Budget (APBD) at both the provincial and district/city levels in Indonesia still largely depends on the State Revenue and Expenditure Budget (APBN). The main component of regional revenue dominantly comes from the DAU and the DAK. Regional revenues, both from the original regional revenue (PAD) component and other legitimate revenues, have not been able to accommodate regional needs in administering government and public services. In addition, the PAD of each region has not contributed significantly to the APBD. 
Karo District as the object of this study also experiences the same problems as the majority of districts/cities in Sumatera Utara or even in Indonesia. Due to the high dependence of regions on the DAU and DAK components, it has caused fluctuations in the total regional income in the last 5 (five) years. In the 2016 fiscal year, there was a decrease in income by 0.9 percent and again experienced an increase in the 2017 and 2018 fiscal years. However, in 2019 it experienced a decline of 4.15 percent from the previous year. The data on regional revenue fluctuations also implies that autonomous regions are highly dependent on the budget from the central government.

Table. 1. Regional Income Fluctuation in Karo (in billion Rupiah)

\begin{tabular}{|c|c|c|}
\hline Fiscal Year & Total Revenue & Percentage of Increase \\
\hline 2015 & 1.470 & 45,46 \\
\hline 2016 & 1.456 & $(0,96)$ \\
\hline 2017 & 1.463 & 0,47 \\
\hline 2018 & 1.495 & 2,18 \\
\hline 2019 & 1.424 & $(4,15)$ \\
\hline \multicolumn{2}{|c|}{ Source: Government of Karo Regency $[13][14]}$. \\
\hline
\end{tabular}

The majority of regional income as mentioned above still comes from non-original regional income (PAD). This PAD also turns out to be fluctuating both in terms of the amount of income and the amount of each type of income. The regional tax and retribution sector have also proven not to be a major contributor to this PAD which implies that the economic sector, especially real estate, has not developed significantly.

There are several factors that cause the high dependence of local governments, especially at the district/city level, on the national budget. This study identifies at least three important factors. Firstly, the lack of PAD is due to the condition of natural resources, geography, demographics, and economic growth that do not contribute significantly to regional income. Secondly, the low capacity and creativity of local governments to intensify or verify the local tax and retribution sector. in the area. Thirdly, national fiscal policy that provides many limitations for regions to optimize regional revenue as well as the extent of the central tax component whose subjects and objects are actually in autonomous regions.

\subsection{Healthcare Deconcentration Funding and its Urgency for the Karo District}

Healthcare services in Indonesia are regulated as a concurrent authority or government affairs which are shared between the central, provinces, and districts/ cities government. In general, the authority is divided into four sectoral affairs namely: healthcare efforts, health HR, provision of pharmaceuticals and medical devices, and community empowerment. The authorities of the central government that have been deconcentrated is generally in the sector of the Health HR sector and community empowerment.

Table 2. Division of Concurrent Authority in the Healthcare Sector

\begin{tabular}{|c|c|c|c|}
\hline Sectoral Affairs & Central Government & Province & Regency/Municipality \\
\hline Health Efforts & $\begin{array}{c}\text { Issuance of licenses for } \\
\text { class A hospitals and } \\
\text { national health service } \\
\text { facilities }\end{array}$ & $\begin{array}{c}\text { Issuance of licenses for } \\
\text { class B hospitals and } \\
\text { health service facilities } \\
\text { at the provincial } \\
\text { level. }\end{array}$ & $\begin{array}{c}\text { Issuance of licenses for class } \\
\text { C and D hospitals and } \\
\text { district/city level health } \\
\text { service facilities. }\end{array}$ \\
\hline Health HR & Standardization and & Provincial health HR & Issuance of practice permits \\
\hline
\end{tabular}




\begin{tabular}{|c|c|c|c|}
\hline & $\begin{array}{l}\text { registration of health } \\
\text { workers and issuance of } \\
\text { recommendations for the } \\
\text { use of foreign workers }\end{array}$ & $\begin{array}{l}\text { planning and } \\
\text { development }\end{array}$ & $\begin{array}{l}\text { and work permits for health } \\
\text { workers. }\end{array}$ \\
\hline $\begin{array}{l}\text { Provision of } \\
\text { pharmaceuticals/ } \\
\text { medical devices }\end{array}$ & $\begin{array}{l}\text { Provision of drugs, } \\
\text { vaccines, medical devices, } \\
\text { and health supplements } \\
\text { for the national program }\end{array}$ & \begin{tabular}{|c|} 
Issuance of \\
acknowledgment of \\
pharmaceutic al \\
wholesaler and branch of \\
medical device \\
distributor
\end{tabular} & $\begin{array}{l}\text { Issuance of licenses for } \\
\text { pharmacies, drug stores, } \\
\text { medical equipment stores } \\
\text { and optical. }\end{array}$ \\
\hline $\begin{array}{l}\text { Community } \\
\text { Empowerment }\end{array}$ & $\begin{array}{l}\text { Empowerment through } \\
\text { national/ international } \\
\text { figures, community } \\
\text { groups, NGO and the } \\
\text { business at the } \\
\text { national/international } \\
\text { levels. }\end{array}$ & $\begin{array}{c}\text { Empowerment through } \\
\text { figures, community } \\
\text { groups, NGO and the } \\
\text { business at the provincial } \\
\text { levels. }\end{array}$ & $\begin{array}{c}\text { Empowerment through } \\
\text { figures, community groups, } \\
\text { NGO and the business } \\
\text { at the regency/municipality } \\
\text { levels. }\end{array}$ \\
\hline
\end{tabular}

Source: Adopted from Law 32/2004.

The context of deconcentration fund as a logical implication of the regulation on administrative decentralization is interpreted as a form of funding originating from the APBN implemented by the Governor as the representative of the Government which includes all revenues and expenditures in the context of implementing deconcentration activities, excluding funds allocated to central vertical agencies in the regions. Deconcentration activities that are financed are non-physical in nature, including, among others, synchronization and coordination of planning, facilitation, technical guidance, training, counseling, supervision, research and surveys, guidance and supervision, and control [15]. Basically, this funding context has not adjusted to Law No. 23 of 2014, where the meaning of deconcentration has been expanded. The researcher predicts that in the future there will be a change in regulations regarding deconcentrated funding following the original intentions of the latest regulation on decentralization.

Healthcare sector funding by local governments is still a separate note to this day. On one hand, as previously described, it is a basic service, but on the other hand, there is still a reluctance of the autonomous regions to budget for healthcare services as a priority [1]. This condition ultimately makes the deconcentration program still need to be maintained or at least the withdrawal of the program and its budget is carried out incrementally while waiting for regional independence or including this component in the DAU and DAK of each autonomous region.

The healthcare service on the other hand has also become a national commitment, at least through the regulation of Law No 36/2009 concerning Health. In this regulation, it is clearly stated that the provincial and district/city government allocated a minimum of 10 percent of the regional revenue and expenditure budget excluding salaries. However, this is still very difficult to realize up until the present. Other facts show that long before the healthcare law was enacted, autonomous regions, especially districts and cities together with the ministry of health, had committed in 2000 to prioritize a budget of at least $15 \%$ of their respective APBD regions [16]. However, in fact, in 2001, as many as 22 districts/cities only allocated a maximum of $5.3 \%$ of their respective APBD. In fact, in total, only 2 districts have allocated a health budget above $10 \%$ of the total APBD, namely Deli Serdang District in Sumatra Utara Province (10.7\%) and Gorontalo District in Gorontalo Province (13.2 \%) [17]. This condition 
again implies the need for funding from other sources outside the district/city APBD, including funding through a deconcentration scheme.

The healthcare deconcentration fund for Sumatera Utara Province in the last three years has tended to decline. If in 2017 the total deconcentration funds amounted to Rp.64,90 billion, it decreased to Rp. 52.1 billion in 2018. This figure has decreased again to Rp. 43.6 billion in 2019. This downward trend actually does not only occur for the province of Sumatra Utara, but also occurs in almost all provinces in Indonesia. Looking at the distribution of national deconcentration fund allocation data in the last 3 years, the consistency of this decline has occurred. On one hand, this reduction is in line with the national strategy to reduce health program assistance for regions from central government funds, and on the other hand, it is a dilemma for regions that at the same time the balance funds through the DAU and DAK components have not increased.

The healthcare sector deconcentration program is in fact relatively static in the sense that the diversification of programs and activities has not changed for at least the last two years. The programs and funding for the province of Sumatra Utara in 2018 and 2019 are relatively the same, consisting of seven programs or menus. The programs are management support, national health insurance, community health development, healthcare service development, disease prevention and control, pharmaceutical and medical devices, and the health human resources development and empowerment program.

Table 3. Deconcentration Budget Allocation for Sumatera Utara Province in 2018 and 2019 (in Billion Rupiah)

\begin{tabular}{|c|l|c|c|}
\hline No & \multicolumn{1}{|c|}{ Programs } & $\mathbf{2 0 1 8}$ & $\mathbf{2 0 1 9}$ \\
\hline 1. & Management Support & 2,34 & 3,20 \\
\hline 2. & National Health Insurance & 1,87 & 1.87 \\
\hline 3. & Community Health Development & 30,24 & 15,26 \\
\hline 4. & Health Service Development & 2.74 & 2,18 \\
\hline 5. & Disease Prevention and Control & 6.09 & 15,34 \\
\hline 6. & Pharmaceuticals and Medical & 2.24 & 2.55 \\
\hline 7. & HR Development & 6.58 & 3.21 \\
\hline \multicolumn{3}{|c|}{ Source: Government of Sumatera Utara Province [16][18]. } \\
\hline
\end{tabular}

The human resource development sector is an important component that can be utilized by Karo District in relation to this deconcentration funding. It is realized that funding for capacity building for medical and non-medical personnel for the government is very limited in programs and budgets in the APBD, especially in the Healthcare Office budget. Based on the study results, it is found that the HR development program only amounts to Rp. 66.07 million in 2018 and Rp. 91.85 million in 2019. These figures are only 0.12 percent and 0.14 percent of the total healthcare service budget in the years. The total budget for health services through the Karo District Health Office in 2018 and 2019 is 55.54 billion and 64.78 billion respectively.

Table 4. Health Office Budget Allocation for HR Development (in Million Rupiah)

\begin{tabular}{|c|c|c|c|c|}
\hline \multirow{2}{*}{ Name of Program } & \multicolumn{2}{|c|}{2018} & \multicolumn{2}{c|}{2019} \\
\cline { 2 - 5 } & Amount & Beneficiaries & Amount & Beneficiaries \\
\hline $\begin{array}{l}\text { Partnership for quality improvement } \\
\text { of doctors and medics }\end{array}$ & 66.07 & 36 person & 91.85 & 38 person \\
\hline
\end{tabular}


In this condition, the Karo district government really needs funding to improve the quality of doctors and medical personnel. An informant from the Karo District Health Office conveyed that there are many kinds of training needed by doctors, medical personnel and nonmedical personnel at the karo health office, not only training which is general in nature in the sense that it is needed by the majority of districts/cities in North Sumatra but also special training related to localities and special endemics in this region.

The deconcentration program as lastly regulated through PMK No. 156/PMK.07/2008 is non-physical, including technical guidance and training. Related to this program of strengthening the capacity of human resources, healthcare deconcentration activities for the province of Sumatera Utara allocate programs and budgets specifically for this activity as described in Table 4. An Informant from the Healthcare Office in this study said that Karo District is always involved in training activities or strengthening the capacity of medical personnel. and non-medical in the health sector, among others, training on handling malnutrition which is funded through a deconcentration fund scheme coordinated by the government of Sumatra Utara Province. Karo District Government can be proactive in planning deliberations on the healthcare sector deconcentration budget and propose priority activities according to regional needs.

Table 5. Budget Allocation for HR Development in Sumatera Utara Province (in Billion Rupiahs)

\begin{tabular}{|c|l|c|c|}
\hline \multirow{2}{*}{ No. } & \multicolumn{2}{|c|}{ Programs } & \multicolumn{2}{|c|}{ Year } \\
\cline { 3 - 4 } & & $\mathbf{2 0 1 8}$ & $\mathbf{2 0 1 9}$ \\
\hline 1. & Improving the Quality of HR & 0,295 & - \\
\hline 2 & Health HR Training & 4,210 & 0,871 \\
\hline 3 & Planning and Utilizing HR & 0,541 & 0,635 \\
\hline & Total & 5,047 & 1,507 \\
\hline
\end{tabular}

Source: Government of Sumatera Utara Province [16][18].

\subsection{Responses and Criticisms of the Healthcare Sector Deconcentration}

Deconcentration funding in general covering various public service sectors, both basic and advanced services, is designed to be transferred to be part of the DAK scheme for local governments. This is very logical considering that many functions that should be the authority and responsibility of the autonomous regions are funded through a deconcentration scheme. In the provisions of Article 108 Paragraph 1, Law No. 33/2004 concerning Financial Balance between the Central and Regional Governments, it is stated that "deconcentration funds and co-administration funds which are part of the budget of the state ministries/institutions are used to carry out functions which according to laws and regulations become regional affairs, gradually being transferred to DAK". The law clearly states that state ministries/ institutions activities that have become regional authorities/affairs should no longer exist but rather be transferred to the regions in the form of DAK scheme [19].

In general, local governments at both the provincial and district/city levels welcomed and supported the deconcentration program in the healthcare sector. Since the healthcare services are part of public services and based on the fact that regions have not fully been able to finance health services from independent funds, this healthcare sector deconcentration funding is considered strategic. There are several positive points for the autonomous regions related to funding this deconcentration sector.

Firstly, there is a transfer of knowledge and information technology from the central government to the regions [20]. The training programs provided by the central government 
through the deconcentration fund scheme usually bring in national experts or trainers who have reputations for developing healthcare services. This can be used by the autonomous regions to share experiences with the experts or trainers in the program. Secondly, the deconcentration program can help improve public services in the healthcare sector that are not yet covered in the autonomous regional budget. Its presence can cover programs that have not been accommodated by regions in their annual budgets. The disease prevention and control programs, pharmaceutical and medical device programs, as well as development and empowerment programs for health human resources, are concrete examples in this case. Thirdly, increasing the welfare of local government officials. It must be realized that a series of activities through a deconcentration scheme is accompanied by a financing honorarium for program managers or participants. For participants in several activities, it also includes a component of honorarium payments. For regional officials who are involved, especially those from districts/cities with low-performance allowances, this program is very helpful.

Besides the positive meaning of deconcentration funding, it does not mean that this program is free from criticism. An informant from the Sumatra Utara government saw that in some cases, the standard of program implementation set by the central government through state ministries/institutions is too high if it is related to local conditions so that the activity achievement indicators did not always go according to the original plan. Another thing is the very minimal program coordination, monitoring, and evaluation so that the program menu is relatively unchanged from fiscal year to fiscal year. The healthcare program as the object of this study is an example of how static the menu and health deconcentration activities are. Finally, informants from the Karo District government saw the lack of coordination between the provincial government as the holder of the deconcentration program and the districts/cities as autonomous regions. In many cases, district/city governments are simply not involved in deconcentration activities carried out by provincial governments in their jurisdictions or geographical area. In fact, the provincial government actually has no citizens from the perspective of demographic administration. The district/city governments basically own citizens so that any deconcentration activities carried out by the central government through the provincial government should be coordinated with them.

\section{Conclusion}

Karo Regency is not yet fully autonomous, especially due to its high dependence on funding from non-local revenue (PAD). The lack of PAD has consequences for the low number and proportion of the healthcare service sector outside of the apparatus salary. The annual budget of the healthcare office, as the spearhead of health services at the district level budgeted, is very little for programs and funding for strengthening human resources so that active involvement in training activities or strengthening apparatus capacity through deconcentration funding coordinated by the province is very strategic for the region.

\section{Acknowledgment}

The authors would like to thank the Deputy for Strengthening Research and Development, Ministry of Research and Technology of the Republic of Indonesia/the National 
Research and Innovation Agency through Lembaga Penelitian USU in the budget year of 2020 for funding this study.

\section{References}

[1] B. C. Smith, Decentralization: the territorial dimension of the state. Taylor \& Francis, 1985.

[2] P. Bardhan, "Decentralization of governance and development," J. Econ. Perspect., vol. 16, no. 4, pp. 185-205, 2002.

[3] G. S. Cheema and D. A. Rondinelli, Decentralization and development: Policy implementation in developing countries. Sage Publications, 1983.

[4] H. Nadeak, "Studi Dana Dekonsentrasi dan Tugas Pembantuan di Lingkungan Kementerian Dalam Negeri," J. Bina Praja J. Home Aff. Gov., vol. 4, no. 1, pp. 45-56, 2012.

[5] B. Bungin, Analisis data penelitian kualitatif. PT RajaGrafindo Persada, 2007.

[6] J. W. Creswell, "Penelitian kualitatif \& desain riset: memilih diantara lima pendekatan," Yogyakarta: Pustaka Pelajar, 2015.

[7] $\quad \Sigma . \Lambda \alpha \delta$, "Good governance and public administration reform in the Black Sea Economic Cooperation (BSEC) Member States,” 2008.

[8] E. Prasojo, Reformasi kedua: melanjutkan estafet reformasi. Penerbit Salemba, 2009.

[9] R. J. Bennett, Decentralization, local governments, and markets: towards a post-welfare agenda. Clarendon Press, 1990.

[10] D. K. Hart, "Theories of government related to decentralization and citizen participation," Public Adm. Rev., vol. 32, pp. 603-621, 1972.

[11] UNDP-Government of Germany Evaluation, Decentralization: A Sampling Of Definitions. Working Paper: Joint UNDP-Government of Germany Evaluation, 1999.

[12] D. A. Rondinelli, J. R. Nellis, and G. S. Cheema, "Decentralization in developing countries," World Bank Staff Work. Pap., vol. 581, 1983.

[13] Pemerintah Kabupaten Karo, Laporan Pertanggungjawaban Anggaran Tahun 2018. Kabanjahe: Bappeda, 2019.

[14] Pemerintah Kabupaten Karo, Laporan Pertanggungjawaban Anggaran Tahun 2019. Kabanjahe: Bappeda, 2020.

[15] Regulation of Minister of Finance No 156/ PMK. 07/2008. .

[16] Pemerintah Provinsi Sumatera Utara, Lakip Dinas Kesehatan Provinsi Sumatera Utara Tahun 2019. Medan, 2020.

[17] E. Sitorus and A. Nurwahyuni, "Analisis Pembiayaan Kesehatan Bersumber Pemerintah Di Kota Serang Tahun 2014-2016,” J. Kebijak. Kesehat. Indones., vol. 6, no. 3, p. 138, 2017.

[18] Pemerintah Provinsi Sumatera Utara, Lakip Dinas Kesehatan Provinsi Sumatera Utara Tahun 2018. Medan, 2019.

[19] W. D. Kusuma and V. A. Soeprapto, "EFEKTIVITAS PENGALIHAN DANA DEKONSENTRASI DAN TUGAS PEMBANTUAN KE DANA ALOKASI KHUSUS," $J$. Anggar. dan Keuang. Negara Indones., vol. 2, no. 1, p. 24, 2018.

[20] F. Trimurni, "Decentralization of Public Healthcare Service in The Province of Sumatera Utara, Indonesia," University of Malaya, 2019. 